In ethnology and anthropology, the term tradition usually denotes transmission over time and continuity of phenomena, while recent views also highlight other aspects. Because of disappearance of "typical" cultural phenomena it became a value. Since it has connected people on many levels, it can be perceived as a means of identity politics. At the same time it becomes a strategy to strengthen a sense of belonging and achieve diverse goals. These aspects are presented with some empirical examples.

Keywords: tradition, ethnology, anthropology, identity, tourism.
Vetnologiji in antropologiji izraz tradicija navadno označuje prenašanje kulture skoz čas in kontinuiteto kulturnih pojavov, medtem ko novejsi pogledi poudarjajo tudi druge vidike. Zaradi izginjanja "značilnih «kulturnih fenomenov je postala vrednota. Ker povezuje ljudi na mnogih ravneh, jo razumemo kot sredstvo identitetne politike. Hkrati postaja tudi strategija za krepitev obcutkov pripadnosti in za dosego drugih ciljev. Ti vidiki so vzorčno predstavljeni zempiricnimi zgledi.

Ključne besede: tradicija, etnologija, antropologija, identiteta, turizem.

Many events in Slovenia, as well as elsewhere in Europe, are being advertised as traditional, meaning that they have either been taking place for a number of (or at least two) years or that they serve to present old cultural elements. Throughout history, tradition has been an important idea in various economic, social and political spheres, usually denoting a phenomenon or a set of phenomena that have been passed on from generation to generation and finally settled in the life of a community; something that has become notable in an activity over its long lifespan; an activity itself, taking place over a longer period of time; and even implying value or achievement, rarely also meaning (oral) lore (cf. DSLL). In ethnology and anthropology, the term tradition usually denotes transmission over time and continuity of phenomena, while recent views also highlight tradition as a strategy to add value to phenomena. That implies that tradition has many aspects.

Discussions about tradition are among the oldest discourses in central European ethnology. Notwithstanding, traditions are often understood as a set of universally valid cultural features, ways, customs and bad habits, freely and eternally floating in the bosom of space and time of a society, nation and/or nation state ... Modern history shows that ... [such] interpretations of traditions... form an ideal ground for manipulations on the part of authorities and politics, which repeatedly use ideological interventions to create a consciously defined relation to the past. (Brumen 2001: 203) 
One of the well-known examples of such appropriation, in which ethnographers played an important role, is the nationalisation of folk culture, one of the tools of instituting and reinforcing the identity of the Slovenian (or any other) nation. ${ }^{1}$ Since the 19 th century, by spreading narration on nationalism and romantic ideals, establishing legitimacy and defining specific spaces, structures, objects or phenomena distinctive of a certain national culture, European social and political elites have encouraged the discourse on heritage, accentuating the importance of its preservation, raising public awareness of its significance, using it to inspire patriotic sentiments, etc. (Smith 2006: 22-23). Together with the birth of nation states, the term national heritage also occurred, denoting a body of folkways promoted by political elites and national institutions on which new regimes founded their identity (Davison 2008: 31). The role of ethnographers was mainly collecting extraordinary items and interpreting them in a way that suited those purposes.

The culture defined with tradition (e.g. folk culture) is therefore an important element of disciplinary tradition. Because of disappearance of "typical" past cultural phenomena it was understood as a value. Since it has connected people not only at national, but at many other levels, it can be perceived as a means of identity politics. Instead of arguing how a community is unified because of tradition, nowadays researchers are challenged to observe how tradition is used in creating a community. In this sense, tradition becomes a strategy to strengthen a sense of belonging and also achieve various goals. These aspects are further presented with some examples from recent research.

\section{TRADITION AS A VALUE}

During the process of shaping and defining ethnological scholarship, as well as after it, the fundamental changes brought on by industrialisation with its side effects (technologisation, bureaucratisation, standardisation, urbanisation, social fragmentation, individualisation, commercialisation, etc.) supposedly caused the disappearance of tradition. Among scholars, this encouraged a search for the so-called survivals, which were used to reconstruct the development of a culture, trace its expansion, assess its authenticity, etc. In the Slovenian territory, research into survivals was relatively rare with the exception of research on specific segments of material culture (settlements, buildings), and to some extent the culturalhistorical analyses of customs, whereas a distinctly positive stance on these phenomena, and a critical, sceptical, pessimistic and even negative attitude towards the changes incited by modernisation, were a frequent occurrence. The disappearing or changing tradition supposedly led to the loss of "our" culture, identity, values, morality, originality/distinct character, etc. Therefore, ethnology and folklore studies became (especially in their beginnings) a

1 A contemporary equivalent of this process is the localisation of tradition, with local communities trying to determine their distinguishing features in order to put a community on the tourist map or to have them as their new identifying symbols. 
national as well as moral project: their primary goal was to search for, and preserve, the oldest, original if possible, forms of culture, which were perceived in a distinctly positive way just because they were fading away; those forms embodied preferred moral qualities and were also used to justify national aspirations.

By definition, history should always contain a model of an original to be (re)produced for various purposes in the present; while the accuracy or faithfulness (authenticity) of this reproduction in the present is assessed by its similarity to the original design. This way, places, objects, images and even people are not merely modern creators or context-dependent complex items of the present, they are there as markers of past events, periods, lifestyles. In this sense, "traditional" means not only old, but also original, authentic (Taylor 2001: 9). In Slovenian ethnology, as well as other European national ethnologies comparable with German Volkskunde, the context of the "original”, at least before 1960's, was the socalled folk culture, i.e. a uniform, non-stratified peasant culture of the preindustrial era. Countryside where majority of inhabitants of Slovenian ethnic origin lived was seen as the basis where Slovenian culture derives from; and towns (with predominantly German or Italian population) and urban way of living were understood as a part of foreign cultural sphere. People therefore felt the need to preserve the traditional (i.e. domestic) culture and way of life (Uršič and Hočevar 2007: 62, 64) which were often idealised because of their fading, or, more specifically, because of their transformations. In today's anthropology, this phenomenon is associated with the notion of "a rural idyll".

The concept of the rural idyll refers to meanings which "rural/country/peasant" has in a predominantly urban socio-cultural environment. This is always a positive image; the countryside is often portrayed (and perceived) as a land "flowing with milk and honey" where one can go "back to nature", while a period of living in such a place is seen as "the golden age" or "the good old days". The rural idyll is an urban construct, a product of urban imagery as an antipode to a city and urban lifestyle (Bell 2006: 150). In accordance with this view, people use the notions of rural and urban to evaluate their identities and give sense to their lifestyles, with "rural" implying ideas of a lifestyle that people see as more natural, complete, harmonious (Rapport and Overing 2004: 315).

Despite changes that have occurred in the rural environment and in what it signifies, the ideological representations of the rural in general and a rural lifestyle specifically have never left the past. In popular discourse, the rural is still regularly being portrayed as a natural and timeless space in which old(-fashioned) values and the lifestyles, i.e. traditions, associated with them, are still (barely) alive. The rural idyll is the core of representation and reproduction of the rural for recreational purposes, with idyllic representations having a visible impact on how the development of the countryside is being encouraged, be it as a migration process or tourism (Vepsäläinen and Pitkänen 2010).

This phenomenon is also manifest in the rural environment in and around the village of Janče to the north east of the City of Ljubljana. By early 1990's, agriculture had played a minor economic role in the area. Farming was in decline, the main activity was livestock 
production (with an average of five head of livestock per farm), and fruit production was in its early stages of introduction. Crafts and services were underdeveloped, supplementary activities were too few, and tourism was almost non-existent. The area was subject to urbanisation, cultural activities started to fade away and dispersed settlement affected interpersonal ties (self-sufficiency of farms, little communication). The area also suffered from bad utility services and a shortage of drinking water. It had poor road connections and public transportation. Its economic and demographic structures were unfavourable, with high out-migration figures, a weak sense of community and significant unemployment rates (Maslo and Markovčič 2003). In 1993, the inhabitants established the Besnica - Janče Tourism Society, and started to implement a project of the "Integrated rural development and village renewal programme" in the valley of Besnica and Janče, developed on their own initiative in cooperation with the Ministry of Agriculture, Forestry and Food, and the then municipality Ljubljana Moste - Polje. The aim of the project was the establishment of home businesses (sale of strawberries, butter, cheese, milk, eggs, liquors, and other produce) and the development of the home catering industry (tourist farms), with urban visitors as the target audience. Through the project, the first Slovenian Strawberry Country Festival was organised in Janče in 1994, later to be replaced with Strawberry Festivals and Chestnut Sundays, and a public site for events was built alongside a playground. In order to sell crops and produce at events, they established the Fruit Route association (Sadna cesta) in 1996 to comply with law restrictions and establish a common brand. After the project had concluded, the City of Ljubljana contributed to a further development and maintenance of quality cultural landscape and the preservation of population levels even in the most remote areas of the municipality with the programme Coexistence of City and Countryside (Sožitje med mestom in podeželjem) and its Rural Development Programme. Until 2011, 37 different entities (farms, a plant nursery, herb garden business, and a foundry studio; some of them already resigned) joined the Fruit Route association, which, as a section of the Besnica - Janče Tourism Society, won the award for special achievements and unique rural development model by the European Association for Rural Development (ARGE) in 2004. In 2007, the municipality joined the new European "Leader" programme of rural development (by 2013) (Markovčič 2005; Markovčič and Pintar 2004).

In the 1990s, after implementation of the first of the rural development projects and programmes, the population started to increase; the median age in the area in question dropped and the ageing index, associated with a birth rate increase and higher in-migration figures, sank below the Slovenian average. One of the main reasons incomers give for their decision to migrate is the quality of life, i.e. peace, quiet, a good environment to raise children, etc., while in their school projects children also indicate a vision of living and working on a farm or doing other tasks/jobs needed in the local area. Tourism has started to develop, also with the emergence of tourist farms, which mostly advertise their services with a peaceful and cultivated (i.e. farming) environment, home-grown, organic food, architectural heritage and other idyllic components of the countryside. Part of this idyllic image is also farm 
activities, a fact proven by displays or competitions in traditional farm practices organised by locals at their public events. These demographic and tourist indicators show that people ascribe some special value to the area and lifestyle in question, while the local population sees this as a good potential for development, and knows how to use it.

\section{TRADITION AS A MEANS OF IDENTITY POLITICS}

In the 19th century, Slovenian collectors and researchers of folk material labelled the most picturesque, interesting elements of culture of the predominantly peasant population as national goods, national treasures etc., using them to illustrate cultural richness and uniqueness, and with it originality and equality of the Slovenian nation with other European ones. Their successors elevated local or regional elements into national ones, nationalising folk culture to create and enforce a sense of national identity. In doing so, ethnographers tampered with tradition, reworked and reinvented it, with the intention of preserving it and "saving it from slipping into oblivion". Thus, ethnology in its beginnings was characterised as "a national rescue action" (Löfgren 1990: 4), and with this ambition ethnology gained prominence in European countries as an academic discipline of national importance. Even after the demise of the cultural-historical paradigm in the 1960's, some Slovenian ethnologists called for the "preservation of our folk life" (cf. Kuret 1962: 1) or condemned distortions of folklore (i.e., folklorism), not giving much thought to the fact that they, with the purpose of constituting and maintaining tradition as a binding element of national identity, modified tradition themselves and (in the broadest sense of the term) manipulated it.

Because folklore ("items" of culture) was conceptualised as a vanishing culture, as much of it needed to be collected, documented, and included in special classification schemes, i.e. archives and collections, as quickly as possible. As in the case of artefacts, a similar observation can be made for cultural practices: ethnographers conducted field research to document everyday and festive practices, classifying them by ethnological categories and sorting them into archives. Their ideological and research agendas, i.e. the need to preserve and the aspiration to classify, often made them disregard the context which a certain practice was embedded in. With their interest, they valued some practices higher than others, attributing to some of them special grandeur, festivity, and uniqueness, which their practitioners never truly felt. Traditional (manual) farm activities, which are often presented as festive, may serve as an example of overestimation of certain daily practices.

Folklore therefore started to speak through collections (in the broadest sense of the word). Although nowadays efforts to display local identity are increasingly frequent, these displays do not really differ from displays of national identity that prevailed as the process of collecting began; presented is a utopian whole, local or national. Defining the local and establishing its symbols is a trans-local process in which each locality produces its own identity in the context of more or less similar identification processes, both within 
the borders of nations and states, as well as outside them. In these processes, localities use localized competitive strategies and a heightened sense of awareness of what makes a place special and gives it a competitive advantage, and it is often traditional practices and artefacts that do so. Although such strategies have local characteristics, these are nationally and internationally standardised models, which affect local variations and advocate what gives them a competitive advantage. In addition to manifesting local identity, the similarity of the model and the contents displayed contribute to the construction of national culture (Anttonen 2005: 112, 85).

This phenomenon has been, in my opinion, best described with the term glocalization, coined by Japanese economists in the late 1980s, but popularized by British sociologist Roland Robertson. It denotes globalization of the local as well as localization of globality and refers to all individuals, groups, units, institutions, communities, etc., which are supposed to "think locally and act globally" (Robertson 1995). Glocalization is also understood as a concern for the local, as a reaction to globalization, where the local has to be recovered, packaged and sold as "heritage « which has become an unifying strategy in some parts of the West (Coleman and Crang, in Smith 2006: 73). Global characteristics influence the revitalization of locality; globalization is a new way of stressing the local. Global actually means translocal; cultural elements, in the past distinctive only for a specific culture or place, appear in translocal exchange, dialogue and conflict (Beck 2003: 70-71). Glocalization can be, for example, seen in the fact that similar phenomena, i.e. displays of similar traditional elements of culture at events or a generally similar course of events which the village in question (Janče) became famous for, can be found in other villages around Ljubljana, e.g. blueberry festival in Mali Lipoglav, cherry and strawberry festival in Češnjica, country feast and autumn festival in Zadvor, chestnut Sunday in Velika Štanga; while similar events relate to typical produce, crafts or traditional (farm) activities also take place elsewhere in Slovenia and in many places around Europe.

Thus, tradition as a global hyphen (AlSayyad 2004: 23) of various identities has become a means of identity politics. However, folklore researchers nowadays pay increasingly less attention to how united a group can be due to its folklore (tradition), and instead focus more on how folklore (tradition) is used in the group's activities, in processes of population categorisation, in setting boundaries in certain environments and crossing them in others, and in defining relations between the categories created this way (Anttonen 2005: 105).

In the examined area, the strongest communities are the ones that incorporate some form of tradition in their activities. One of the ways the local tourism society uses to bring people together is through their events, where they show local tradition, such as old farm activities, food typical of the area or made from ingredients typical of the area, and folk costumes. Events are one of the most important segments of social life in and around Janče, bringing together people from the villages of the area at least once a year, as well as fostering their ties with people from neighbouring areas. Less formal short-lived communities are also formed while practicing traditional activities, such as preparing bread dishes or making paper 
flowers. Traditional economy, i.e. farming, is a further important motive for creating good neighbourly relations; farmers help each other when working on fields or share machinery, and those with tourist farms buy produce from their neighbour farmers when needed.

\section{TRADITION AS A STRATEGY}

In Slovenia, tradition has been "in full bloom" for at least the last two decades. People collect everything that passes as old, traditional, and display this as part of their private collections, at events and in many other ways. Their intention is no longer only to preserve the heritage of their ancestors; they also have economic and other motives. To attract as big an audience as possible, they use various marketing techniques, i.e. they "sell" tradition/ heritage. ${ }^{2}$ This way, tradition is used as a strategy to either improve one's own economic position or to enhance the development of the local environment as a whole. It is most often used in tourism, acquiring new forms and functions (i.e. being revived as folklorism).

In the late 20 th century, when peripheral areas in many countries started to undergo economic restructuring, rural tourism became a development strategy. Rural resources, which were traditionally the basis for primary sector activities (agriculture), started to be used to achieve different goals. Local population increasingly often looked for alternative ways to make income, and tourism was where many saw an opportunity to do so. This was also encouraged with the projects for rural development and other programmes. In the last decades, states and state alliances (European Union, United States of America) also recognized the potential of rural tourism and promoted it as the means to resolve (mitigate) economic and social problems of peripheral rural areas, especially where people have abandoned traditional agricultural sectors, and provided considerable support and means for its development. In the area in question, tourism began its intense - and above all planned - development in the 1990s with the project of Integrated rural development and village renewal. People started to organise public events, presenting their countryside heritage.

2 Terms tradition and heritage are often used synonymously (cf. Bogataj and Fikfak 2004; Slavec Gradišnik 2004). The relation between them is not always clear; tradition generally more often refers to the process of transmission or reproduction of certain practices through time while heritage applies to corpuses, a concrete state or a form at a certain stage of the transferring process, and the representation of past cultural phenomena and practices. According to Wiendu Nuryanti (1996: 249), heritage as a carrier of historical values from the past is viewed as part of the cultural tradition of a society; Pertti J. Anttonen (2005: 39) defines heritage as a presentation of tradition; tradition as an opposition to modernity is an element in processes of creating heritage; and Sanja Kalapoš Gašparac (2009: 330) describes tradition as a process of preserving, based on transference of knowledge and practices for future use, while heritage consists of objects and practices which became unalterable and were excluded (or deliberately eliminated) from the process of tradition. Other authors see the relation between tradition and heritage as the relation between consumption (consumption of tradition for socio-political and cultural identification) and manufacture (manufacturing of heritage mainly for commercial purposes) (see articles in: AlSayyad 2001). 
Modifications of heritage and a romantic-nostalgic view of it, which these events mostly manifest, are typical folklorism. Even though ethnologists have mostly regarded this phenomenon as a "distortion of folklore" or even "fakelore", today they generally agree with the British historian David Lowenthal that we don't need an unalterable heritage (tradition), but the one we can constantly interact with, the one which brings together the past and the present (Lowenthal 1995: 410). Especially heritage tourism provides opportunities to portray the past in the present and the chance to experience the past through the prism of the endless possibilities of interpretations (Nuryanti 1996: 250).

Most activities in the researched area are motivated by a desire for a higher income. By organising exhibitions of strawberries and traditional homemade food, farms can promote themselves and attract potential buyers. A lot of visitors come to Janče to buy these produce on stalls and see displays of traditional farm activities. With the wide recognition these events soon won, organisers no longer needed to display customs and activities to increase their audience figures, so only those have been retained that do not require much space or complex preparations and which involve produce that can be offered to visitors, for example pressing apples for juice. The most explicit indication of folklorism at public events are the so-called folk costumes, which are also used to serve as a means to visualise locality as more attractive and recognisable, bringing farms better economic results, but are now losing this role and are being abandoned. Those members of the tourism society, who don't have farms and therefore have no economic motives for their participation, are involved in organizing events mostly because of the feeling that they contribute to the "welfare", "development" and "promotion" of their village.

In general, local inhabitants from the area in question understand heritage as an important element of identity and (self)representation of their own (local) area. According to the survey conducted by the local tourist society, they see the need to "evident and praise the renovation of any element of architectural heritage to stop its disappearance," and to announce novelties and improvements in renovation of such heritage in order to "popularize all the villages and motivate inhabitants." When suggesting the content of the events, they mentioned "displays of customs from the local area, the way of dressing, speaking, display of making household and economic utensils used in the past, the exhibition of those objects", and - "because we have folk costumes" - they also suggested "display of a dance" and performing it outside local area as well. They desired events "as in the beginning" - i.e. with more presentations of local heritage - because recent ones are "too similar to fairs because of the lack of programme" (Survey). The answers show us that heritage is also interpreted in economic terms. Heritage is the means of self-promotion for the owners of the tourist farms as well for those who advertise their offer on the internet.

Heritage and tradition are, as shown above, used either for strengthening of belonging to different entities either for achieving economic goals. In general, the events incorporating elements of folklorism, i.e. displays of local tradition, helped the population improve their economic situation, and consequently contributed to preservation of agriculture and 
mitigation of out-migration. They also make an important segment of the social life in the Janče area, as local people generally attend at least one spring and one autumn event for their own amusement and to foster relations with their more distant neighbours. Those who complain that development has "destroyed Janče completely" and would prefer "some peace and quiet" are exception.

\section{CONCLUSION}

Local inhabitants in the Janče area employ tradition in tourism in order to "survive" or earn additional income; tradition/heritage used at the local events is one of the factors to attract visitors to the area. Among the most popular and often used elements of tradition are local businesses/activities (agriculture, crafts), culinary (ingredients and dishes) and dress (so-called folk costumes). They usually adopt tradition/heritage that is visually or experientially interesting, adjust it to their needs and expectations of tourists (in this way it lives as a folklorism); some elements are performed (displays of farming activities, crafts), others exhibited (culinary, models of architectural heritage), some are used as part of the offer on stalls (dishes) or as an experience (competitions in mowing or farm wagon construction). Ideal(istic) images of tradition - noticeable especially at local events and in promotional materials of tourist farms - epitomize what may be termed "rural idyll" and become the basis for local development strategies for the area. Agriculture with its ritual practices becomes transformed into a symbol of the area that links inhabitants to different communities, contributing to the development of local tourism and sustainable development.

So what is the role of tradition (or heritage) in the sustainable development in general? Although there is little explicit mention of heritage in strategies of sustainable development, we cannot deny its potential to contribute to various strategic goals. As we have tried to show, projects or activities involving local traditions can help regenerate, strengthen or develop local economy as well as they affect sense of belonging and social integration. Although we have tried to present different aspects of tradition in separate chapters - tradition as a value, as a means of identity politics and as a strategy - we usually can't separate one aspect from another. The attempt of such elaboration was therefore merely to expose characteristics which help us recognize the attitude of tradition performers, their motivations, ways and mechanism of transmission and images that are transmitted.

\section{REFERENCES}

AlSayyad, Nezar (ed.)

2001 Consuming Tradition, Manufacturing Heritage: Global Norms and Urban Forms in the Age of Tourism. London and New York: Routledge. 
2004 Introduction: The End of Tradition or the Tradition of Endings? In: AlSayyad, Nezar (ed.), The End of Tradition? London and New York: Routledge, 1-28.

Anttonen, Pertti J.

2005 Tradition through Modernity: Postmodernism and the Nation-State in Folklore Scholarship. Helsinki: Finnish Literature Society (Studia Fennica. Folkloristica, 15).

Beck, Ulrich

2003 Kajje globalizacija? Zmote globalizma - odgovori na globalizacijo (What is Globalization? Fallacies of Globalism - Answers to Globalization). Ljubljana: Krtina.

Bell, David

2006 Variations on the Rural Idyll. In: The Handbook of Rural Studies. SAGE Publications (http://sage-ereference.com/hdbk_rural/Article_n10.html; 23.9.2009).

Bogataj, Janez and Jurij Fikfak

2004 Dediščina (Heritage). In: Baš, Angelos (ed.), Slovenski etnološki leksikon (The Slovenian Ethnological Lexicon). Ljubljana: Mladinska knjiga, 76.

Brumen, Borut

2001 Umišljena tradicija "dobrih starih časov" (Imagined Tradition of the "Good Old Times"). In: Šmitek, Zmago and Borut Brumen (eds.), Zemljevidi časa. Zbornik ob 60-letnici Oddelka za etnologijo in kulturno antropologijo (Maps of Time: Miscellany for the $60^{\text {th }}$ Anniversary of Department of Ethnology and Cultural Anthropology). Ljubljana: Oddelek za etnologijo in kulturno antropologijo, Filozofska fakulteta, 193-207.

Davison, Graeme

2008 Heritage: From Patrimony to Pastiche. In: Fairclough, Graham (et al., eds.), The Heritage Reader. London and New York: Routledge, 31-41.

DSLL

2005 Slovar slovenskega knjižnega jezika z Odzadnjim slovarjem slovenskega jezika in Besediščem slovenskega jezika z oblikoslovnimi podatki (elektronski vir) (Dictionary of Slovenian Literary Language, electronic source). Ljubljana: SAZU and ZRC SAZU, Inštitut za slovenski jezik Frana Ramovša; DZS; Amebis.

Kalapoš Gašparac, Sanja

2009 Tradicija na pladnju turizma (Tradition on the Tray of Tourism). In: Ceribašić, Naila and Ljiljana Marks (eds.), Izazov tradicijske kulture. Svečani zbornik za Zoricu Vitez (The Challenge of Traditional Culture: Ceremonial Miscellanea for Zorica Vitez). Zagreb: Institut za etnologiju i folkloristiku, $327-335$.

Kuret, Niko

1962 Turizem in folklora (Tourism and Folklore). Glasnik SED 4 (1): 1.

Löfgren, Orvar

1990 The Danger of Knowing What You Are Looking For: On Routinizing Research. Ethnologia Scandinavica 20:3-15.

Lowenthal, David

1995 The Past is a Foreign Country. Cambridge, New York and Melbourne: Cambridge University Press.

Markovčič, Maruška

2005 Zeleni prag Ljubljane - vzhod. Podeželje se predstavi (Green Threshold of Ljubljana - East: Introduction to the Countryside). Ljubljana: Mestna občina Ljubljana, Oddelek za gospodarske dejavnosti in turizem (http://www.ljubljana.si/si/mol/publikacije/?category=68138, 5. 1. 2012).

Markovčič, Maruška and Josip Pintar

2004 Sožitje med mestom in podeželjem (Coexistence of City and Countryside) (www.rralur.si/html/ po_projektih/docs/sozitje_med_mestom_in_podezeljem.pps, 7.9. 2006.) 
Maslo, Gorazd and Maruška Markovčič

2003 Razvojpodeželja na vzhodnem delu Mestne občine Ljubljana (Rural Development on the Eastern Part of the City of Ljubljana)

(http://www.bf.uni-lj.si/iae/Tone/Predstavitev\%20CRPOV\%20.ppt, 26. 2. 2007).

Nuryanti, Wiendu

1996 Heritage and Postmodern Tourism. Annals of Tourism Research 23 (2): 249-260.

Rapport, Nigel and Joanna Overing

2000 Social and Cultural Anthropology: The Key Concepts. London and New York: Routledge.

Robertson, Roland

1995 Glocalization: Time-Space and Homogeneity-Heterogeneity. In: Featherstone, Mike, Scott Lash and Roland Robertson (eds.), Global Modernities. London: Sage, 25-44.

Slavec Gradišnik, Ingrid

2004 Tradicija (Tradition). In: Baš, Angelos (ed.), Slovenski etnološki leksikon (The Slovenian Ethnological Lexicon). Ljubljana: Mladinska knjiga, 635-636.

Smith, Laurajane

2006 Uses of Heritage. London, New York: Routledge.

Survey

s.a. $\quad$ Survey (results) (source without identification information, typescript). Tourist Society Besnica Janče archives.

Taylor, John P.

2001 Authenticity and Sincerity in Tourism. Annals of Tourism Research 28 (1): 7-26.

Uršič, Matjaž and Marjan Hočevar

2007 Protiurbanost kot način življenja (Antiurbanity as a Way of Life). Ljubljana: Fakulteta za družbene vede.

Vepsäläinen, Mia and Kati Pitkänen

2010 Second Home Countryside: Representations of the Rural in Finnish Popular Discourses. Journal of Rural Studies 26 (2): 194-204.

\section{VIDIKI TRADICIJE}

$V$ slovenskem jeziku izraz tradicija splošno pomeni pojav ali skupek pojavov, ki so se s prenašanjem iz roda $v$ rod ustalili $v$ življenju skupnosti; tisto, kar se je uveljavilo v neki dejavnosti med njenim daljšim obstajanjem oz. dlje časa trajajoče dejavnosti; tudi vrednoto oz. dosežek, redko pa (ustno) izročilo. Vetnoloških oz. antropoloških slovarjih, leksikonih in enciklopedijah sta v geslih tradicija poudarjeni prenašanje (posredovanje, dedovanje) skoz čas (iz generacije v generacijo) in kontinuiteta pojavov; v geslih novejših priročnikov je poudarjeno tudi, da je tradicija strategija za dodajanje vrednosti pojavom.

To kaže, da ima tradicija mnoge razsežnosti. Labko jo razumemo kot pomemben element disciplinarne tradicije, saj je bila "s tradicijo opredeljena kultura", tj., ljudska kultura, specificni predmet preučevanja etnologije in sorodnih ved. Poglavitna skrb raziskovalcev so bili prežitki, konkretni, empirično dosegljivi "predmeti « kulture, ki so po nazorskem izročilu evropske etnologije dokumentirali narodovo preteklost. Ker pa so izginjali in so jih naglo prekrivali novi, sodobni 
kulturni pojavi, so narodopisci gradivo tudi na poseben način vrednotili. Ker tradicija povezuje ljudi na mnogih ravneh (od lokalne in nacionalne do globalne), jo labko razumemo kot sredstvo identitetne politike, in novi pristopi izzivajo folkloriste k razpravi, kako je tradicija uporabljena $v$ ustvarjanju skupnosti. V tem smislu namrečpostaja strategija za krepitev občutkov pripadnosti in za doseganje tudi drugih, npr. gospodarskih ciljev. Najpogosteje je uporabljena v turizmu, pri tem pa prevzema nove oblike in funkcije, tj., zaživi kot folklorizem.

Tradicija kot vrednota. Etnologija in folkloristika sta (predvsem v svojih začetkih) postali nacionalni in hkrati moralni projekt: njuna glavna naloga je bilo iskati in ohranjati najstarejše, po možnosti izvirne oblike kulture, t. i. ljudsko kulturo (tj. kmečko), ki so jo izrazito pozitivno vrednotili prav zaradi tega, ker je kopnela pod bremenom civilizacijskih novosti; utelešala je zaželene moralne lastnosti, z njo pa so dokazovali tudi upravičenost nacionalnih zahtev. Njeno idealizacijo lahko povežemo s pojmom podeželska idila; pozitivno podobo ruralnega kot naravnega, harmoničnega, celostnega, ki se oblikuje kot protipol urbanega. Podeželska idila je temeljni del reprezentacije in reprodukcije ruralnega $v$ rekreacijske namene; idilične reprezentacije pa opazno vplivajo na spodbujanje razvoja podeželja, bodisi v obliki priseljevanja ali turizma, kot je to opazno na Jančah. Demografski in turistični kazalniki na raziskovanem območju namreč nakazujejo, da ljudje - predvsem iz urbanega okolja - tamkajšnjemu načinu življenja pripisujejo posebno vrednost, v čemer domačini vidijo dober razvojni potencial, ki ga znajo izkoristiti. Tradicija kot sredstvo identitetne politike. Medtem ko so narodopisci v 19. stoletju regionalne sestavine povzdigovali na raven narodnih posebnosti in tako nacionalizirali ljudsko kulturo, da bi ustvarili in okrepili pripadnost nacionalni identiteti, danes zaznavamo procese lokalizacije tradicije, ko lokalne skupnosti skušajo najti posebnosti, da bi svoje območje postavile na turistični zemljevid ali jih povzdignile na raven identifikacijskega simbola. Tradicija kot globalni vezaj za različne identitete je torej postala sredstvo identitetne politike. Namesto razprave, kako povezana je lahko skupina zaradi svoje folklore oz. tradicije, alternativni pristop danes etnologe izziva $k$ študijam, kako se tradicija uporablja v ustvarjanju skupine. Na janškem območju so najtesneje povezane prav skupnosti, ki v svoje dejavnosti vključujejo določeno obliko tradicije: turistično drustvo, ki skrbi za prireditve s predstavitvami lokalnih tradicionalnih opravil in jedi; občasne fluidne skupine, ki opravljajo tradicionalne dejavnosti v različne namene, npr. pečejo kruh ali izdelujejo cvetje iz papirja za jansko butarico velikanko; in medsosedske skupnosti, ki si pomagajo pri tradicionalnem gospodarstvu, tj. kmetovanju.

Tradicija kot strategija. V obdobju gospodarskega prestrukturiranja proti koncu 20. stoletja je podeželski turizem postal razvojna strategija. Ruralne vire, ki so bili tradicionalno osnova primarni dejavnosti (kmetijstvu), so začeli uporabljati za doseganje drugačnih ciljev. Tudi na Slovenskem raba tradicije ni več motivirana zgolj z ohranjanjem izročila prednikov, pač pa vse pogosteje postaja strategija bodisi za izboljšnje lastnega ekonomskega položaja bodisi za splošni razvoj lokalnega območja. Najpogosteje je v rabi v turizmu, pri tem pa prevzema nove oblike in funkcije, tj., zaživi kot folklorizem. Na janškem območju razvoju turizma sledimo od leta 1993; med mestnimi in okoliskimi prebivalci so se najbolj uveljavile prireditve s predstavitvijo lokalnih tradicij (kmečkih opravil, dejavnosti, prehrane, oblačil ipd.). Večina članov turističnega društva 
ima za sodelovanje na prireditvah in uporabo tradicije ekonomske motive, nekaj pa jih sodeluje zaradi občutka, da s tem pripomorejo k splošnemu razvoju območja. Prireditve, ki so vključevale tradicijo, so prispevale $k$ povečanju prihodka prebivalcev, s tem pa $k$ ohranjanju kmetijstva in zmanjšanju izseljevanja; so tudi pomemben segment družabnega življenja.

Čeprav je $v$ strategijah trajnostnega razvoja malo eksplicitnih omemb tradicijeldediščne, pa labko veliko prispeva k različnim strateškim ciljem. Projekti in dejavnosti, ki temeljijo na lokalni tradiciji, namreč pripomorejo k razvoju in krepitvi lokalnega gospodarstva ter pozitivno vplivajo na občutke pripadnosti in povezanosti skupnosti.

Dr. Saša Poljak Istenič, assistant researcher, ZRC SAZU Institute od Slovenian Ethnology, Novi trg 2, SI-1000 Ljubljana, Slovenia, sasa.poljak@zrc-sazu.si 